日臨外会誌 $65(6) ， 1515-1519,2004$

症 例

重症呼吸障害を伴う間質性肺炎に対する胸腔鏡下肺生検の 2 例

\begin{tabular}{|c|c|c|c|c|c|c|}
\hline \multicolumn{7}{|c|}{ 田市立半田病院外科 } \\
\hline 田 & 瓦 & 久保田 & 仁 & 鈴 & 木 & 秀 \\
\hline 神 谷 & 諭 & 羽 & 雄太郎 & 佐 & 藤 & 太 \\
\hline
\end{tabular}

重症呼吸障害を伴い，間質性肺炎を疑う患者に対し，胸腔鏡下肺生検を行い組織学的 診断をしえた 2 症例を経験したので報告する. 症例 1 は62歳，女性. 労作時呼吸困難を 主訴として受診した。肺活量0.791, 予剆倌に対する割合法 $32 \%$ あった。症例 2 は 74 歳, 男性. 呼吸困難を主訴として受診. マスクにて CPAP $10 \mathrm{cmH} 2 \mathrm{O}, \mathrm{FiO} 20.5$ にて補助換 気が必要であった。2症例とも他検查で診断が確定せず, 胸整鏡下肺生険を施行し, 組 織学的診断を確定しえた。術後経過は良好で，2泟例とも術後 7 日目には内科転科とな り, 内科的治療が開始された。

間質性肺炎の治療法決定のためには組織学的診断が必要となってきている. 胸柾鏡下肺生検は重度の呼吸障害を伴う患者に対しても施行しうる有用な検查であ 3.

索引用語：間質性肺炎, 胸腔鏡下肺生検, 重症呼吸不全

はじめに

近年，間質性肺炎を疑う症例に対して胸腔鏡下 (video assisted thoracoscopic surgery: 以下 VATS) 肺生検が行われてきている，当院では，2002 年 2 月に開始し, 現在までに14例のVATS 生倹が行 われた(表 1)，基礎疾患を有するために，術前呼吸機 能検亘で拘束性障害を示寸症例が多く, 肺活量(以下, $\mathrm{VC}$ )，VC予測值に対する割合 (以下，\% VC) の平均 值は正常範囲以下であった．このうち呼吸障害が非常 に重篤であったが, VATS 生検を行い組織学的に診断 しえた 2 例を，若干の文献的考察を加えて報告する．

症例

症例 $1: 62$ 歳, 女性.

主訴: 労作時呼吸困難.

現病歴: 平成 14 年夏ごろから主訴が出現した. 平成 15年 1 月 15 日, 当院内科初颜。1月27日, 経気管支鏡 的肺生検 (transbronchial lung biopsy：以下 TBLB) を施行されるも確定診断にいたらず，2月10日， VATS生㭘目的に外科に入院した。

2004 年 2 月 10 日受付 2004 年 3 月 30 日採用

〈所属施設住所〉

厂475-8599 半田市東洋町 2-29
既往歴：40年前, 急性虫垂炎.

入院時現症：血圧 $118 / 76 \mathrm{mmHg}$, 目瓜拍66回/分, 体温 $37.1^{\circ} \mathrm{C}$, 呼吸数 27 回/分. 胸部聴診上異常音を特に聴取 せず。

検查所見：胸部単純X線写真（図 1)では両肺下肺 野を中心にほぼ全肺野に間質性の变化が認められた。 来院時血液ガス分析 (room air) では, $\mathrm{pO}_{2} 83.4$ $\mathrm{mmHg}, \mathrm{pCO}_{2} 47.4 \mathrm{mmHg}, \mathrm{HCO}_{3}-29.2 \mathrm{mEq} / 1, \mathrm{pH}$ 7.407と, 若干の $\mathrm{CO}_{2}$ の蓄積を認めるほかは大きな異 常值はなかった。呼吸機能検査では VC $0.791 ％$ VC $32 \%$ と, 強度の拘束性障害が認められた。

臨床経過：2月13日, VATS 生検施行.

術中経過：左側卧位にて，分離肺換気による全身麻 醉下で手術を開始した。片肺換気として右第 6 助間中 渡窩線, 第 6 肋間後腋䈪線より $5 \mathrm{~mm}$ ポート, 第 5 助 間前腋穸線に $12 \mathrm{~mm}$ ポートを㧴入. EndoGIAにてS 2, S 8 の一部を切除した。肺尖部に胸腔ドレーンを挿 入し手術を終了した。

術後経過：術後 4 日目に胸腔ドレーンを抜去し, 術 後 5 日目に酸素投与を中止した。術後 7 日目に内科に 転科し, 術後15日目に退院した。組織学的診断はUIP (usual interstitial pneumonia) であった（表 1 )。 以後,プレドニゾロン $20 \mathrm{mg}$ を隔日投与にて治潦を 
表 1 当院における間質性肺资を疑う症例に対するVATS 生検（2002,2－2003.12）

\begin{tabular}{|c|c|c|c|c|c|c|c|c|c|c|c|c|c|}
\hline & \multirow[t]{3}{*}{ 年齢 } & \multirow[t]{3}{*}{ 性別 } & \multicolumn{4}{|c|}{ 術前肺機能検查 } & \multicolumn{3}{|c|}{ 術前血液ガス分析 } & \multicolumn{3}{|c|}{ 術後 1 日目血夜ガス分析 } & \multirow[t]{3}{*}{ 病理診断 } \\
\hline & & & $V C(1)$ & $\% \mathrm{VC}$ & FEV1.0(1) & V1.0\% & $\mathrm{pO} 2$ & $\mathrm{pCO} 2$ & $\mathrm{AaDO} 2$ & pO2 & pCO2 & $\mathrm{AaDO} 2$ & \\
\hline & & & & & & & \multicolumn{3}{|c|}{$(\mathrm{mmHg})(\mathrm{mmHg})(\mathrm{mmHg})$} & \multicolumn{3}{|c|}{$(\mathrm{mmHg})(\mathrm{mmHg})(\mathrm{mmHg})$} & \\
\hline 症例1 & 62 & $\mathrm{f}$ & 0.79 & 32.0 & 0.60 & 75.9 & 83.4 & 47.4 & 9.6 & 191.5 & 49.6 & 109.2 & UIP \\
\hline \multirow[t]{13}{*}{ 症例2 } & 74 & $\mathrm{~m}$ & 1.49 & 49.3 & 1.29 & 86.6 & 70.3 & 35.5 & 246.3 & 88.0 & 38.3 & 225.4 & DAD \\
\hline & 36 & $\mathrm{~m}$ & 2.44 & 63.0 & 2.14 & 87.7 & 85.7 & 45.0 & 10.1 & 91.7 & 46.9 & 1.9 & LIP \\
\hline & 60 & $f$ & 1.61 & 66.0 & 1.19 & 73.9 & 75.5 & 37.6 & 29.2 & 76.9 & 37.3 & 78.7 & BOOP \\
\hline & 60 & $f$ & 1.74 & 74.7 & 1.46 & 83.9 & 82.5 & 42.1 & 16.8 & 74.9 & 42.4 & 24.1 & UIP \\
\hline & 50 & $f$ & 2.57 & 101.6 & 2.31 & 89.9 & 84.2 & 42.6 & 14.5 & 89.2 & 40.9 & 149.0 & UIP \\
\hline & 59 & $\mathrm{f}$ & 1.38 & 55.9 & 1.35 & 97.8 & 88.4 & 39.8 & 13.7 & 78.1 & 40.3 & 23.4 & BOOP \\
\hline & 71 & $\mathrm{f}$ & 1.48 & 68.5 & 1.27 & 85.8 & 83.5 & 47.7 & 9.1 & 110.7 & 43.0 & 125.1 & 過敏性肺楉炎 \\
\hline & 41 & $\mathrm{f}$ & 2.13 & 76.9 & 1.75 & 82.2 & 85.2 & 42.2 & 14.0 & 73.0 & 42.6 & 25.7 & 好酸球性肺炎 \\
\hline & 55 & $\mathrm{f}$ & 1.40 & 56.5 & 1.20 & 85.7 & 85.5 & 44.9 & 10.5 & 87.3 & 45.7 & 7.7 & Wegener肉芽腫症 \\
\hline & 74 & $f$ & 1.40 & 66.7 & 1.25 & 89.3 & 82.9 & 37.3 & 22.2 & 102.6 & 39.8 & 100.7 & 過敏性肺臓炎 \\
\hline & 66 & $\mathrm{~m}$ & 2.42 & 74.2 & 1.68 & 69.4 & 79.0 & 34.5 & 29.4 & 96.9 & 39.3 & 20.2 & NSIP \\
\hline & 64 & $\mathrm{~m}$ & 2.95 & 88.9 & 2.59 & 87.8 & 88.1 & 39.2 & 14.7 & 78.6 & 38.1 & 25.5 & UIP \\
\hline & 62 & $f$ & 1.75 & 71.4 & 1.63 & 93.1 & 84.6 & 46.9 & 9.0 & 73.2 & 45.0 & 22.6 & UIP \\
\hline
\end{tabular}

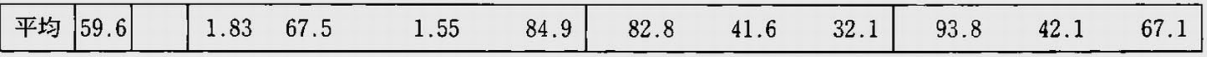

*UIP : usual interstitial pneumonia DAD : diffuse alveolar damage LIP : lymphoid interstitial pneumonia BOOP : bronchiolitis obliterans organazing pneumonia NSIP : non-specific interstitial pneumonia

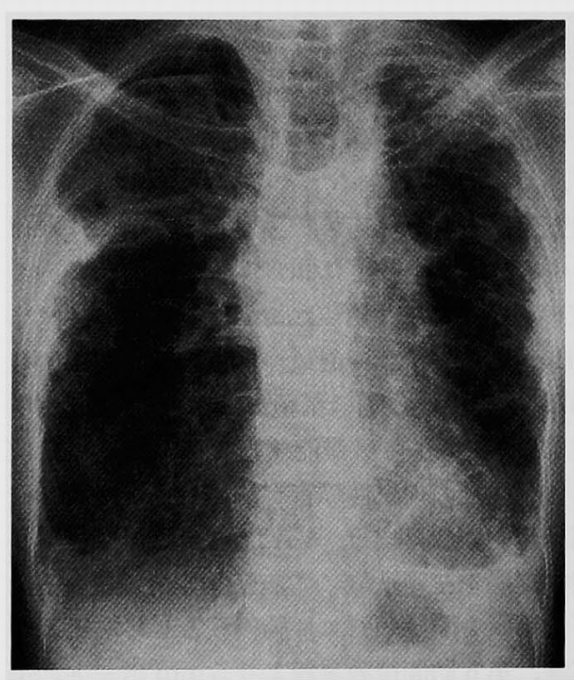

図 1 症例 1 の胸部 X 線写真：下肺野を中心に ほぼ全肺野に間質性の変化がある。

行ったが効果は明らかでなく，プレドニゾロンは中止 し対症療法のみとした. 現在は在宅酸素療法にて外来 経過観察中である.

症例 $2: 74$ 歳, 男性.

主訴：呼吸困難.

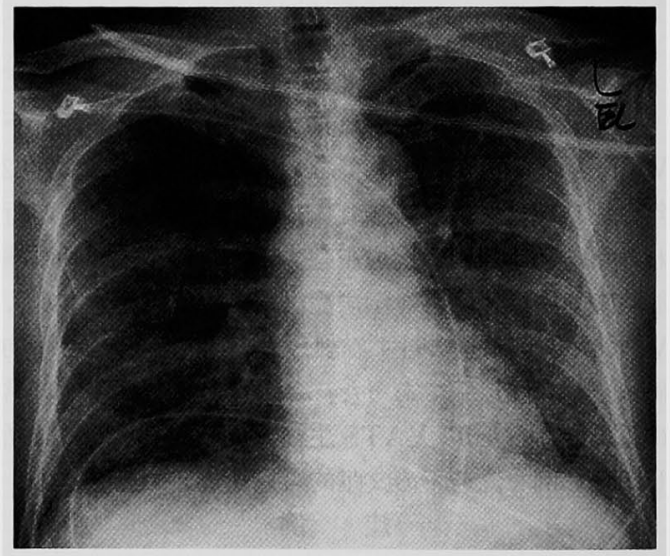

図 2 症例 2 の胸部 X 線写真：全肺野にびまん性に粒 状影, 網状影がみられる。

現病歴: 平成15年 4 月 29 日から呼吸困難が出現し た. 5 月 2 日, 当院救急外来受診.

既往歴：平成 7 年に高血圧, 狭心症, 脳梗塞にて当 院受診, 平成 9 年より陳旧性心筇梗塞, 糖尿病にて, 当院外来通院中.

喫煙歴： 5 年前まで 1 日30〜 40 本.

来院時現症：血圧127/67 mmHg，脈拍112回/分，体 


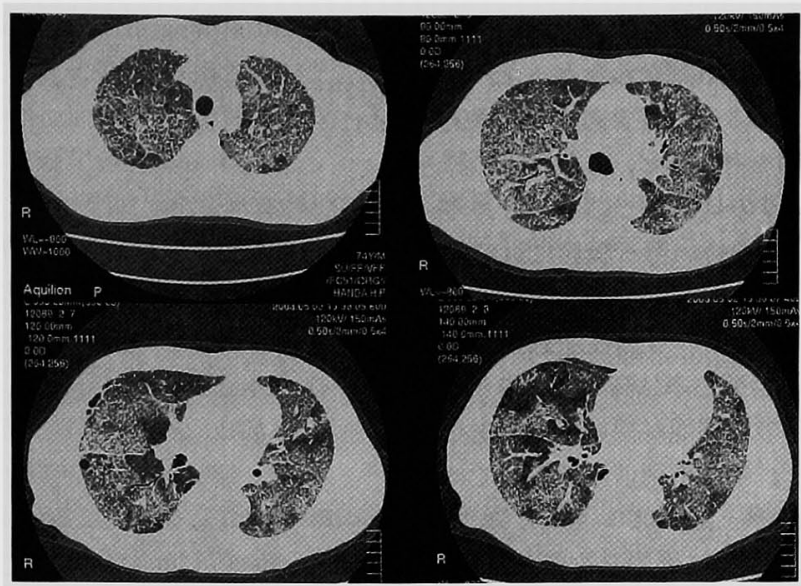

図 3 症例 2 の胸部 HRCT : びまん性に間質の肥厚がみられ honeycomb lung となっている.

温 $36.3^{\circ} \mathrm{C}$, 呼吸数 35 回/分. 胸部聴診上異常音を特に聴 取せず.

検查所見：胸部単純X線写真 (図 2)では全肺野に びまん性に粒状影, 網状影がみられた. 胸部 HRCT(図 3 )では，びまん性に間質の肥厚がみられ honeycomb lung となっていた．来院時血液ガス分析 (room air) にて, $\mathrm{pO}_{2} 35.7 \mathrm{mmHg}, \mathrm{pCO}_{2} 24.3 \mathrm{mmHg}, \mathrm{HCO}_{3}-17.3$ $\mathrm{mEq} / \mathrm{l}, \mathrm{pH} 7.471$ と, 高度の低酸素血症が認められた. 呼吸機能検査では, VC 1.491, \% VC 49.3\% と, 強度 の拘束性障害が認められた。

臨床経過：重症呼吸不全と診断され, 同日 ICU 入院 となった. マスクにて CPAP $10 \mathrm{cmH} 2 \mathrm{O}, \mathrm{FiO} 20.5 に$ て呼吸補助が必要であった。このとき, 肺胞動脈血酸 素分圧較差 (以下, $\mathrm{AaDO}_{2}$ ) は計算上 $246 \mathrm{mmHg}$ と強 度の拡散障害が認められた. TBLB を行うも確定診断 にはいたらず，5月 7 日VATS生検を施行した。

術中経過：右側臥位にて分離肺換気による全身麻酔 下で手術を開始した。片肺換気として右第 6 助間中腋 窩線, 第 6 助間後腋窩線より $5 \mathrm{~mm}$ ポート, 第 5 肋間 前腋窩線に $12 \mathrm{~mm}$ ポートを㨉入.この時, 動脈血中酸 素飽和度 (以下 $\mathrm{SpO}_{2}$ ) が70\%に低下. 手術操作を中断 し両肺換気としたところ, $\mathrm{SpO}_{2}$ は95\%まで回復した. 再度片肺換気とし EndoGIA にてS 2, S 6 の一部を切 除した。この時も, $\mathrm{SpO}_{2}$ が70\%前後まで低下したため, 手術操作を中断し両肺換気とした. $\mathrm{SpO}_{2}$ の回復を確認 後, 肺尖部に胸腔ドレーンを挿入し手術を終了した。

術後経過：気管内抻管状態にて ICU へ退室. 術後 1
日目に抜管し, マスクにて CPAP $10 \mathrm{cmH}_{2} \mathrm{O}, \mathrm{FiO}_{2} 0.5$ で呼吸管理を行った。術後 2 日目に胸腔ドレーンを抜 去. 術後 7 日目に内科転科となった。詳細な組織学的 診断が決定する前に，少なくとも感染性の肺炎でない と判明した時点でプレドニゾロン $500 \mathrm{mg}$ を 3 日間投 与するステロイドパルス治療を行った. 組織学的診断 は DAD (diffuse alveolar damage) であった（表 1 ). 以後, 同様のステロイドパルス治療を 2 回行ったが, 原病の悪化によって 6 月28日死亡した。

\section{考察}

VATS 生検は, TBLBに比べ組織が十分に採取で き診断率が高い。また，開胸肺生検にくらべ侵襲が少 ないが診断率には差がない1).このため, 間質性肺炎を 疑う症例に対して確定診断をする目的で広く行われて いる。しかし，間質性肺炎を疑う症例では，肺機能が 低下している症例が多い，さらに，分離肺換気での全 身麻醉が必要であり, 手術侵襲が加わるため, 手術可 能な症例を的確に判断する必要がある.

これまで報告されているVATS 生検の症例のうち 具体的な数値の記述がある例の肺機能をみると VC が $1.221 ％ \mathrm{VC}$ が $43.2 \%$ が最低值であった ${ }^{2) 41}$. 症例 1 では\% VC が32\%とこれまでの報告例よりかなり低い 肺機能であったが，術後合併症なく手術を行いえた。 また, 症例 2 のように術前より呼吸補助を行わなくて はならないはどの呼吸障害を伴う患者に対する VATS 生検は検索しえた範囲では報告がされていな

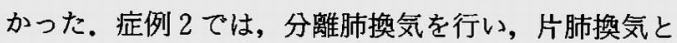


なった值後より $\mathrm{SpO} 2$ が70\%まで低下し，一度手術操 作を中断し，両肺換気にしなければならなかった。片 肺換気が可能な時間はおよを 3 分程度であった。手術 操作を行うのに必要な時間を考えると，これ以下の肺 機能ではVATS 生検を行うのは困難であると考えら れ, 肺機能的にVATS 生検を行い得る限界に近い症 例と考えられた。

TATS生検はその手術侵裂により急性增悪の可能 性があり，急性増悪した場合死亡率は高いと報告され ている6. 急性增悪は術前の肺機能が悪いほど発生し やすいとの報告があるが4!，年龄や術前の肺機能では 差岋ないとの報告もあり方一定していない。また

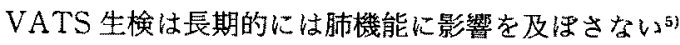
が，術後に一時的に肺機能が低下することもあるた め778)，術後合併症なく経過するために注術前の肺機能 を正確に評価することが重要である。

現在間質性肺炎の治療法決定には組織学的猃断が必 要となることが多く”，正確な診断を行うためには VATS 生検は必要な手技である。

当院で経験した症例の検討により,VATS 生検は重 度の呼吸障害を伴う患者に対しても施行しうる有用な 検査であるといえる。

$$
\text { まとめ }
$$

きわめて重症の呼吸障害を伴う間質性肺炎疑い症例 に対し, VATS 生検を行い組織学的診断をしえた 2 例 を経験したので, 若干の文献的考察を加えて報告した。

\section{文献}

1) Rena $\mathrm{O}$, Casadio $\mathrm{C}$, Leo $\mathrm{F}$, et al: Videothoracoscopic lung biopsy in the diagnosis of inter- stitial lung disease. Eur J Cardiothorac Surg $16: 624-627,1999$

2）浦本秀隆，大崎敏弘，能勢直弘他：間質性肺疾患 に対する胸然鏡下肺生検の意義。産業医大誌 $23: 45-50,2001$

3）盛山恭子, 岩政浩子, 須加原一博：胸腔鏡下肺生 検術後の肺機能変化およびその有用性. 麻醉 $44: 1623-1626,1995$

4）榎本達治, 川本雅司, 功刀しのぶ他：胸憖鏡下肺 生検後仁急性増悪した特発性肺線維症症例の検 討. 日呼吸会誌 $40 ： 806-811 ， 2002$

5) Daniil Z, Gilchrist FC, Marciniak SJ, et al : The effect of lung biopsy on lung function in diffuse lung disease. Eur Respir J 16:67-73, 2000

6）金沢 実，河端美則，高柳 昇他：び慢性肺疾患 の外科的肺生検アンケート.日呼吸会誌 $38: 770$ $-777,2000$

7) Miller JD, Urschel JD, Cox G, et al : A randomized, controlled trial comparing thoracoscopy and limited thoracotomy for lung biopsy in interstitial lung disease. Ann Thorac Surg 70 : $1647-1650,2000$

8）成松紀子, 田代雅文, 須加原一博他: 胸腔鏡下肺 生検と開胸肺生検の麻醉中合併症と肺機能変化。 臨麻 $20: 1467-1470,1996$

9）星野勇馬，長井苑子：気管支肺胞洗净法, 経気管 支肺生検，胸腔鏡下肺生検の意義と適応。最新医 $56: 2529-2534,2001$ 


\title{
VIDEO-ASSISTED THORACOSCOPIC LUNG BIOPSY IN PATIENTS WITH SUSPECTED INTERSTITIAL PNEUMONIA AND SEVERE RESPIRATORY DYSFUNCTION
}

\author{
Wataru SUMIDA, Hitoshi KUBOTA, Hideaki SUZUKI, \\ Satoshi KAMIYA, Yutaro ASABA and Taichi SATO \\ Department of Surgery, Handa City Hospital
}

We report 2 cases of severe respiratory dysfunction in which pathological diagnosis was made by video-assisted thoracoscopic lung biopsy.

The first patient, a 62-year-old woman admitted for effort dyspnea, had a vital capacity of 0.791 , which was, $32 \%$ of the predicted value.

The second patient, a 74-year-old man admitted for dyspnea, required respiratory aid with mask$\mathrm{CPAP}$ at a pressure of $10 \mathrm{~cm} \mathrm{H}_{2} \mathrm{O}$ and an oxygen concentration of $50 \%$.

Pathological diagnoses were made in both cases with thoracoscopic lung biopsy after other examinations failed to yield satisfactory diagnoses.

Both patients showed a good postoperative course and were transferred to the department of internal medicine 7 days after surgery for continued treatment.

Pathologic diagnosis is becoming necessary for the treatment of patients suffering from interstitial pneumonia.

Thoracoscopic lung biopsy is useful for examination and can be clone even in patients with severe respiratory dysfunction. 